\title{
СУСПІЛЬСТВО ЗНАНЬ: СПОКУСИ ОНОВЛЕННЯ І ПАСТКИ УТОПІЧНОЇ СВІДОМОСТІ
}

\author{
М. Д. Култаєва
}

д. філос. н., професор, член-кор. НАПН України, завідувач кафедри філософії Харківського національного педагогічного університету імені Г. С. Сковороди

Суспільство знань і як теоретичний конструкт, і як нова соціальна та культурна реальність, що конституюється на основі культури інформаційного суспільства, є викликом, адресованим не тільки теоретикам, а й усьому людству. Сам термін «суспільство знань», як відомо, набув широкого поширення ще наприкінці XX століття. 3 одного боку, усвідомлення нового статусу знання як суспільно-конститутивного чинника стало поштовхом для реставрації просвітницьких ілюзій щодо використання знань, а відтак і освіти та виховання як потужного ресурсу радикального оновлення сучасних соціумів, а з іншого - спонукало до осмислення нових реалій продукування, функціонування та репрезентації знань у дійсних і гіпотетичних соціокультурних контекстах. Виведення цієї проблематики на рівень макросоціологічних узагальнень не може обмежуватись нормативними описами гіпотетичного конструкту суспільства знань, а потребує аналізу тих культурних механізмів і практик, які б забезпечили його існування, самоорганізацію і саморозвиток.

Методологічна програма комплексного суспільствознавства дозволяє з'ясувати статус знання у нових соціальних і культурних констеляціях, а також розкрити амбівалентність соціокультурних тенденцій, що виникають внаслідок конституювання суспільства знань.

Варто зазначити, що теоретичні розвідки у цій проблемній площині в останні роки характеризуються посиленою інтенсивністю. Серед праць, де радикальні культурні зрушення розглядаються із урахуванням перспективи конституювання суспільства знань, треба назвати дослідження В.П.Андрущенка, Б. Гізена, К. П. Лісмана, С. Ф. Клепка, М. І. Михальченка, В. Пазенка, С. В. Пролеєва, П. Слотердайка, Р. Штіхвє та ін.

Внаслідок культурологічного повороту (cultural turn, kulturwissenschaftliche Wende) у західній філософській та соціологічний думці набули поширення міждисциплінарні дослідження тих реалій, які виникають внаслідок конструювання нової соціальної і культурної реальності на основі знання. Контури цієї реальності, що вимальовуються на тлі інформаційного суспільства, накладаються на мрії та сподівання щодо подолання складнощів, проблем і суперечностей сучасного суспільного життя. Суспільство знань як евристична метафора $\epsilon$ своєрідною обіцянкою щодо відкриття нових перспектив для освіченого людства, яке вже навчилося виробляти надмір наукового і паранаукового знання, щоб використовувати його інструментально, екзистенціально та функціонально. Але разом із цією тенденцією у теоретичних обгрунтуваннях конструкту суспільства знань простежується також інша, менш оптимістична, еволюційна можливість, виявити яку дозволяє методологічна перспектива культуральної соціології (Дж. Александер, Б. Гізен, В. Танчер).

Конкуруючими парадигмами у концептуалізації суспільства знань упродовж останніх років $є$ стадіальна і культуральна парадигми. Перша, разом з лінійно-процесуальною, протягом досить тривалого часу залишалась домінуючою. В іiі річищі й сформувалось оптимістичне уявлення щодо континуальної еволюції суспільства знань. Схематично таке уявлення можна унаочнити у вигляді послідовного ланцюга «інформаційне суспільство — суспільство знань - суспільство освіти». Такий ланцюг нагадує відомі схеми суспільного розвитку класичної соціології та марксизму. Це певною мірою пояснює домінування зазначеної парадигми на пострадянському просторі. Варто також нагадати, що соціуми з соціалістичним минулим та постсоціалістичною теперішністю $\epsilon$ суспільствами хронічного дефіциту, які постійно сподіваються на диво прориву і разом з цим на всякий випадок шукають дешеві ресурси та бонуси для наздоганяючої модернізації, потенціал якої не відповідає їхнім занадто високим амбіціям. Суспільна свідомість таких соціумів орієнтується на утопічні проекти, реалізація яких передбачає використання невичерпних ресурсів, яким і $є$ знання, якщо не брати до уваги передумови його продукування і трансляції. При цьому суспільство знань розглядається як більш високий ступень розвитку суспільства саме на тій підставі, що воно грунтується на вже згаданій вище «економіці знання». Як приклад - висновок, який робить російський дослідник В. А. Колпаков, підсумовуючи досвід концептуалізації суспільства знань у західній філософській і соціологічні й думці, започаткований П. Дракером. Зокрема він пише: «Виходячи 3 наявності такого джерела інформації, як знання, виникає тенденція вважати термін «суспільство знання» тотожним терміну «інформаційне суспільство», розкриваючи при цьому основні джерела виробництва та поширення інформації» [1: 27]. У річищі стадіального підходу витримані також політологічні та культурологічні концептуалізації феномену різкого зростання економічної і соціокультурної значущості знання із гіпотезою щодо посилення його суспільної значущості та гуманістичної спрямованості [як приклад див. 2].

Називаючи суспільство знань атопічним [термін Г. Вільке, див. 19: 58-59], тобто принципово позатериторіальним, багато дослідників оптимістично оцінюють перспективи його розвитку, спираючись переважно 
на політико-економічну аргументацію (П. Дракер). Наведемо типову логіку такої аргументації: «Якщо хтось віддає капітал або землю, то страждає через втрату, бо вже не володіє ними. Але той, хто передає знання, залишає своє знання при собі. Знання принципово може копіюватись у будь-який спосіб, якщо воно вже одержано. Споживання землі, праці та капіталу потребує максимальних витрат, бо підпорядковано логіці нульових сум. Адже той, хто обробляє землю або витрачає свій капітал не може повторно застосувати цей ресурс» [19: 60]. Отже, знання тут інтерпретується у дусі ідеології Просвітництва як невичерпний та невитратний ресурс розвитку людини і суспільства. Це супроводжується реставрацією старої ілюзії, що духовне виробництво $\epsilon$ набагато менш витратним, ніж матеріальне, покладеної в основу політики постсоціалістичних країн. Конструкт суспільства знань, побудований на такому підгрунті, добре вписується у теорії техногенної цивілізації, постіндустріального та інформаційного суспільств, де теза щодо економізація знань використовується як змістовне наповнення, так і з метою конкретизації цих схем. В них формалізуються конститутивні чинники та ресурси, які забезпечують еволюційні зміни суспільств, що дає також самі формальні підстави для аналогій суспільства знань з індустріальним суспільством. Наприклад, стверджується, що воно «ставиться до знання так само, як індустріальне до нафти» $[11 ; 16 ; 19]$.

Принципово інші теоретичні перспективи осмислення проблематики суспільства знань відкриваються через перенесення його у площину філософії освіти і культуральної соціології. Зокрема з'являються теоретичні підстави для розгляду його у модусах постсекулярного суспільства, суспільства ризику, споживання, розваг тощо. Це дозволяє прояснити важливі моменти конституювання суспільства знань. Так, прискорення трансляції знань у глобальних комунікаційних мережах, їхнє відносне автономне існування у комунікативній послідовності «інформація - повідомлення - розуміння» здатне створювати ситуації дезорієнтації, соціального і культурного збентеження. Знання, які прискореними темпами конституюють нові реалії, породжують також і нові міфи. Останні приховують ті ризики, які виникають у новій соціокультурній реальності. Щоправда, це має не тільки негативний, а й позитивний аспект. Адже міфотворчість завжди супроводжує суспільні інновації, виконуючи своєрідну терапевтичну дію - пом'якшуючи травматичні наслідки прискорених соціокультурних трансформацій. Суспільство знань - це передусім активне і динамічне суспільство. Воно для свого існування потребує постійного нарощування темпів інновацій, але із урахуванням їхніх соціокультурних наслідків.

Запропонований нижче аналіз, з одного боку, сприятиме встановленню спільних моментів у різних концептуалізаціях змін у культурі сучасних суспільств, що обумовлюють їхнє перетворення на суспільство знань, а з іншого - передбачає виявлення передумов, шансів і перспектив модернізації сучасної освіти. В свою чергу це вимагає критики тих уявлень, що покладені в основу теоретичного конструкту суспільства знань, бо це $є$ передумовою розкриття його евристично насиченого, але амбівалентного потенціалу у практичній площині - на рівні культурної та освітньої політики та рівні відповідних культурних та освітніх практик.

Дійсно, інформаційне суспільство, яке поступово перетворюється на суспільство знань, створює свій культурний ландшафт та свою інформаційну субкультуру. Більшість дослідників вбачає у цій культурі подальше розгортання об'єктивного процесу переходу до «ноосферної цивілізації», сходячись у тому, що «характерними ознаками культурного виміру інформаційного суспільства $€$ антропізація, гуманізація та етизація всіх складових буття людини. I хоча ці тенденції ще далеко себе не реалізували, постійно гальмуються опором прагматичних, ринково-зумовлених чинників, відчувають на собі могутній вплив споживацьких стереотипів та гедоністичних настроїв, їх наявність дедалі виступає виразніше, а кількість їх прихильників постійно зростає» [3: 32-33].

У цілому погоджуючись 3 наведеним вище висновком, треба зауважити, що культура інформаційного суспільства сама провокує споживацькі настрої і стереотипи поведінки соціальних акторів. Далеко не виключена можливість, що гоголівський Пацюк може символізувати освічену людину постіндустріальної доби. Адже у кіберпросторі глобальних мереж пропонується знання, вже готове до споживання, треба тільки вміти своєчасно і вправно відкривати рота. Інтелектуальний фаст-фуд, як різновид культурного варварства, може спричинити духовну деградацію навіть тих суспільств, які сьогодні знаходяться в авангарді цивілізаційного процесу. У такій культурі - а це дається взнаки вже зараз - формується споживацьке ставлення до знання. Сучасна людина у даному випадку наштовхується на межі своїх адаптаційних можливостей. Як слушно зауважує відомий критик цієї тенденції К. П. Лісман: «Забувати непотрібне і навчатися новому є максимою, на яку повинен орієнтуватися член суспільства знань, разом з цим це є тим міфом, яке суспільство знань само розповідає про себе» [12: 17].

Саме через це в останні роки у західному дискурсі посилилась критика як самого теоретичного конструкту суспільства знань, так і тих тенденцій у культурі та освіті, які пов'язуються зі становленням нових суспільних реалій внаслідок трансформацій постіндустріального зразка. Деміфологізація суспільства знань у методологічній перспективі культуральної соціології здійснюється вже не за рахунок альтернативних теоретичних пропозицій і теоретичних розвідок в окресленій площині, а на підставі емпіричних фактів і спостережень за культурними практиками інструменталізації знань у конкретних суспільствах, що вже зазнали на собі наслідки перетворень постіндустріального зразка. Наведемо міркування К. П. Лісмана щодо можливостей, створюваних 
суспільством знань. «Суспільство знань, - пише він, - не є якимсь особливо розумним суспільством. Заблудження і помилки, які робляться у ньому, недалекоглядність та агресивність тут не зменшуються порівняно з іншими суспільствами, сумнівним видається навіть те, чи буде у ньому більш високим рівень освіти. ... У цьому суспільстві вже ніхто не навчається для того, щоб знати більше, а виключно для самого навчання. Адже кредо суспільства знань полягає у тому, що усяке знання дуже швидко старіє і втрачає свою цінність» [12: 16-17].

Небезпека деградації культури у суспільстві знань, на яку вказує К. П. Лісман, небезпідставна. Вона обумовлена тим, що вже на ранньому етапі його становлення значно посилюється розрив між об'єктивною і суб'єктивною культурою. Остання, відокремлюючись від освіти, знижує свій рівень, стає споживацькою і розважальною. В свою чергу цьому сприяють об'єктивні процеси постіндустріального розвитку з відповідними соціокультурними зрушеннями. Разом з цим суспільства знань як таке, що характеризується надміром знань і безперервним потоком інформації, демократизує інтелектуальні форми дозвілля, перетворюючи знання на інструментарій та матеріал азартних ігор. Виграти мільйон, вибороти титул самого розумного тощо сьогодні стає популярно розвагою, а для деяких людей - майже професією та сенсом життя. Можна без перебільшення сказати, що споживачі знання у постмодерній культурі, перетворюючись на шоуменів, відсувають на задній план тих, хто продукує та передає знання - науковців та викладачів, які здебільшого не мають габітусу публічної людини і втрачають свою статусну позицію у розважальній версії суспільства знань. Так, людина-енциклопедія, або людина-довідник стають центральними фігурами шоу-бізнесових проектів, де знавці, ерудити від шкільного до пенсійного віку виступають агентами відтворення знання для розваги або через азарт, притаманний грі на гроші.

Вважаючи такі шоу невід’ємною складовою суспільства знань, К. П. Лісман звертає увагу на те, що тут йдеться не про цілісне, а про пунктуально-фрагментарне знання, тобто про знання фактів, через це в усіх таких розважальних програмах «розмиваються межі між здогадуванням, припусканням, знанням та освітою... Таке шоу, і цим, мабуть, обумовлюється його привабливість, симулює ті рухи та дії у просторі знань, які знає і може відтворити кожний. ... Отже, знання презентується як послідовність питань з різних предметних сфер, які не мають між собою жодного зв'язку і є випадковими. Контингентність стає єдиним принципом, який утримує разом надмір інформацій та значень, про які у надзвичайно швидкому темпі запитується у шоу, чинник випадковості тут відіграє провідну роль» [12: 14-15].

Але інтелектуалізація розваг має також й позитивний бік, бо вона у свій спосіб стимулює пізнавальну активність широких верств населення, спонукаючи пересічну людину до самоосвіти, щоправда у вузько прагматичному сенсі, бо рушійною силою тут виступає не пізнавальний інтерес, а привабливість можливої винагороди у грошовому еквіваленті. Паралельно в рамках цієї культури постійно — як відповіді на запит часу — створюються нові міфологеми, сприяючи ренесансу утопічного мислення, яке міцно укорінене передусім у свідомості пострадянських суспільств, де мрії про так зване «світле майбутнє» з обіцянками щасливого життя і добробуту водночас висміюються і потаємно приховуються як оберіг спільнот, зневірених і втомлених від очікувань покращення умов свого життя. В рамках цієї свідомості, викривленої численними соціальними травмами і патологіями, класична формула модерну «знання-сила» перетворюються на гасла «знання-зиск» і «знання-розвага».

Становлення інформаційної культури у глобалізованому світі, як відомо, супроводжується соціальним і культурним відчуженням, синонімом якого у сучасному дискурсі стає «ексклюзія», тобто маргіналізація певних верств суспільства через виключення їх з економічних, культурних та політичних процесів. Це загострює соціальні конфлікти. Як зауважує один з визнаних фахівців з проблем християнської соціальної етики Р. Маркс, «раніше конфлікт був між верхівкою суспільства та низами, а зараз він $\epsilon$ вже не вертикальним, а горизонтальним, тобто йдеться про інклюзію та ексклюзію, себто про включення або виключення із структур суспільного життя» [14; 109]. Це зауваження має принципове методологічне значення для виявлення амбівалентності настанов, вимог, культурних стандартів та орієнтацій суспільства знань. Вони також $є$ насиченими як утопічними, так і антиутопічними ідеями. Так, просвітницька техноіділлія у вигляді утопії безконфліктного гармонійного суспільства, існування якого підкріплене інформаційними технологіями, не може не викликати захоплення як гіпотетичне втілення масштабних просвітницьких програм, передусім гуманізації влади, посилення ролі інтелектуальних еліт у життєдіяльності складно структурованих динамічних соціумів. Щоправда, ейфорія від перспективи остаточної перемоги знання над невіглаством, світла розуму над темрявою заблуджень і забобонів зводиться майже нанівець через нагадування про владний потенціал знання, який у добу постіндустріальних трансформацій реалізується на якісно новому рівні. Сподівання на гуманізацію владних відносин через перетворення суспільства знань на суспільство освіти є досить поширеною новітньою утопією, яка грунтується на адаптованих до сучасності ідеях Просвітництва. Адже той факт, що знання у різноманітних його формах і репрезентаціях входить до повсякденного життя пересічної людини, ще не є запорукою їі саморозвитку. Більш того, амбівалентні тенденції розвитку культури і суспільства, що знайшли прояв в останні десятиліття, дали підстави для визначення сучасної культури як «нового варварства» (culture as a new barbarism) через нерозбірливе споживання знеціненого 
знання [4: 11]. Однією з передумов запобігання такої нерозбірливості $є$ посилення суспільної уваги до світоглядної культури та гуманістично спрямованої освіти.

Теоретичний конструкт постсекулярного суспільства, запропонований Ю. Габермасом, також можна вважати спробою дати відповідь на виклики сьогодення. Зокрема, він пропонує розглядати і відповідно використовувати релігію як ресурс для продукування гуманних смислів [див. 6: 13]. Отже, постсекулярні культуральні структури здатні виконувати функції охоронця «субстанції гуманного». Г. Йоас зауважує у цьому зв'язку: «Говорячи про постсекулярне суспільство, ми маємо на увазі не зростання значущості релігії або поновлення уваги до неї, а зміну позиції секулярної держави та громадськості щодо існування релігійних спільнот та тих імпульсів, які від них походять» [9: 124-125]. Так, сакральні смисли сприяють ствердженню пост конвенціональної моралі, соціальної відповідальності.

Варто нагадати, що усвідомлення єдності знання, освіти та моралі бере початок ще з часів античності. Але тільки у 19 ст. в рамках неогуманістичної парадигми відбувається взаємопроникнення понять освіти у ії широкому сенсі, а саме: як формування гуманної людини, (Bildung) і знання. Це мало потужний евристичний потенціал і надало поштовх розвитку нових культурних форм і ствердженню нових моделей життєтворчості. Ці поняття, так само, як свобода і саморозвиток людини та людства у цілому формують серцевину гумбольдтіанської ідеї університету. У контексті цієї ідеї знання ототожнюється з істиною, а призначення і покликання вченого - а саме він у цій парадигмі є вихователем і вчителем людства — передусім пов'язано з відданим служінням їй. Героїзація і сакралізація діяльності вченого мала соціальні наслідки, формуючи суспільну повагу до діяльності науковців та вчителів. Останнє в західних розвинутих суспільствах зберігається і дотепер (на відміну від країн пострадянського простору).

Варто зауважити, що диференціація знання і спеціалізація наукового виробництва вимагають більш критичного ставлення до уявлень щодо начебто закономірного перетворення інформаційного суспільства на суспільство, конститутивним чинником якого стає освіта. Таке перетворення є радше контингентним, тобто таким, що може відбутися або ж не відбутися в умовах постмодерної культури. Цей тип культури визначає культурний смисл і статус знання в різних конструктах постіндустріального суспільства та відповідно у конкретних умовах розбудови його структур. Якщо відійти від теоретичного конструкту суспільства знань і розглянути його прообрази, риси яких набувають визначеності у конкретних соціокультурних контекстах, то напрошується висновок про множинність модифікацій цієї соціокультурної реальності. Навіть те, що потенціал цього суспільства складається із знань, не усуває, а посилює ризики нового суспільства. Адже навіть історично успадковані знання перетворюються на постмодерні, бо несуть на собі відбиток нової доби, ії культурних технік і стандартів, уподобань та інтелектуальної моди. Вимога прискорення тут висувається не тільки до наукового виробництва принципово нового знання, а й до інтерпретацій та реінтерпретацій. Як слушно зауважує Ліотар, постмодерне знання позбавляється своєї сакральності, бо «старий принцип, за яким здобування знання було нерозривно пов'язано 3 формуванням духу та особистості, зазнає все більшого занепаду... Знання виробляється і буде вироблятися на продаж, воно споживається і буде споживатися у новому виробництві, в усякому разі для того, щоб бути предметом обміну. Воно перестає бути своєю власною метою» [13: 23-24].

Гуманізувати таке комерціалізоване знання суто засобами освіти і виховання є надзвичайно важким завданням. Це обумовлюється тим, що сучасне наукове знання є надзвичайно розгалуженим. Воно втрачає свою цілісність, стає спеціалізованим, а демаркації між науковим і ненауковим знанням - нечіткими і розмитими. Принцип постмодерної плюральності торкається також і самоорганізації знань як в освітньому просторі, так і у життєвому світі. Теоретичний конструкт суспільства знань, який синтезує економічні, соціологічні, культурологічні і політологічні версії подальшого розвитку сучасних складноструктурованих суспільств, сам несе відбиток так званого дифузного, чи нерозбірливого модерну [див. 18: 81]. Це знаходить прояв у тенденції усунення ієрархії між різними культурними формами знання, у розмиванні меж між науковим знанням і повсякденним досвідом, у легітимації так званого забороненого знання про «темний бік людської природи». К. П. Лісман зауважує у цьому зв'язку: «У суспільстві знань, більш, ніж у будь-якому іншому, соціально заборонене знання збігається з індивідуально забороненим, тобто інтеоризованим знанням, бо через скасування офіційних заборон у сфері сприйняття і передачі інформації ця функція змушено перекладається на внутрішні інстанції » [11: 19].

Культурно-еволюційний підхід до визначення знання у якості фундаментальної основи нового типу суспільної реальності, розкриває принаймні напрям його дійсної і подальших само репрезентацій. Так, якщо у домодерну добу знання було скарбом (звідси походить метафора про скарбницю знань), у модерну — «силою», «владою» та культурним капіталом, то у постмодерній версії його символом може бути сховище, музей і навіть кімната для іграшок. Модерні міражі суспільства знань і ті його контури, які вимальовуються у постсучасних соціокультурних контекстах, мають принципові відмінності, хоча в обох випадках висувається вимога підпорядкування його людині. 
Демократизуючи доступ до знання, акцентуючи його суспільну цінність, суспільство пізнього Модерну демократизує також знання як таке. Комплементарність сцієнтизму і антисцієнтизму у духовній культурі сучасних розвинутих суспільств, широке продукування дидактичних адаптацій наукового і паранаукового знання у вигляді методичних посібників, порад, рецептів тощо починає руйнувати успадковану від попередніх епох ієрархію різних форм знання, внаслідок чого суттєвою ознакою суспільств пізнього Модерну стає дефіцит виважених і відповідальних орієнтацій. Відтак і суспільство знань у його подальшій еволюції може виявитися «суспільством дезінформації» (Desinformationsgesellschaft), яке продукує брехню, плітки, удосконалює техніки підбору компромату тощо [12: 17]. Мінімізувати наслідки такої тенденції розвитку суспільства знань засобами освіти і виховання навіть у теоретичній площині $є$ важким завданням. Адже те, що Т. Адорно називав «напівосвітою» (Halbbildung) видає себе за освіту, а так звана «мас-медійна педагогіка суспільства розваг» бере на себе роль вихователя і наставника молоді [12: 59].

Надзвичайне прискорення виробництва знань, окрім цього, само підштовхує людину до пошуків освітніх симулякрів. Суспільство знань у його версії «суспільства розваг» (Unterhaltungsgesellschaft) дозволяс, нехай лише на певний проміжок часу, затримати потік продукування знання. Адже його прискорення загострює проблему співвідношення між новим і старим знанням, між знанням і незнанням. Розглянемо дещо детальніше соціально-антропологічне підгрунтя цієї проблеми. Так, не зважаючи на відмінність модерної і постмодерної культур знання (Wissenskulturen), між ними простежується внутрішній зв'язок. Адже пізнання як наукова і культурна творчість обумовлює складні відносини між старим і новим знанням. Нагадаємо, що модерна теоретична традиція, фіксуючи тенденцію старіння знання, рішуче віддає перевагу новому, а постмодерна культура на противагу цій традиції намагається обгрунтувати можливість співіснування Старого і Нового. Обидві можливості певною мірою вплинули на визначення рис і перспектив суспільства знань, сприяли перетворенню цього конструкту зі статичного на динамічний.

Суспільство знань, принципом існування якого є надмір продукування наукових і культурних інновацій, певною мірою порушує баланс між Новим і Старим в онтогенезі людини. Останнє може стати причиною не тільки психічних а й соціальних патологій, спричинюючи кризу орієнтації людини і соціумів через девальвацію знань, цінностей та світоглядних пропозицій. Загроза ствердження нігілізму постійно супроводжує ті культурні трансформації, які пов'язуються зі становленням суспільства знань. Так, Лісман вбачає симптоми появи «практичного педагогічного нігілізму» через зосередження вчителів не на змісті, а на формі навчального процесу. [12: 36]. Але найбільш уразливою перед спокусами нігілізму є молодь, яка в силу своїх вікових психологічних характеристик завжди готова із запалом руйнувати старе, захоплюватися ілюзіями, перебувати у полоні мрій, віддано служити ідеям радикального оновлення світу. Радикальний нігіліст ніколи не буває старою людиною. Він переживає у неадекватний спосіб розчарування у старих суспільних цінностях і крах власних життєвих настанов та ідеалів. Суспільство знань, якщо воно буде нездатним здійснювати самоконтроль за своїм розвитком і самоопис своїх станів, може створити сприятливий грунт для паростків аксіологічного і навіть гносеологічного нігілізму з його деструктивними наслідками. «Віддання переваги Новому, - наголошує А. Тремль, — це дуже ризикована еволюційна стратегія. Ми намагаємося тим самим опанувати, схопити зростаюче прискорення нашої соціокультурної еволюції, але з цього може нічого не вийти. ... Уперше в історії культури наш світ через його самоіндукцію змінюється так швидко, що старе, випробуване знання змінюється в межах одного покоління так швидко, що втрачає свою корисність (перевірену в минулому). Наслідком цього стає надзвичайне посилення значущості дитини, отже, нової людини, але це не повинно не відбуватися за рахунок знецінення старої» [17: 74]. Розрив внутрішнього зв'язку між генераціями має руйнівні наслідки і для людини, і для культури, бо його наслідком є перспектива кінця історії, кінця цивілізації, зрештою — кінця індивіда.

Це є викликом для виховання у сучасних суспільствах, бо воно у його цивілізаційному вимірі $є$ антропологічною константою. Як зауважує А. Тремль, первісною функцією виховання є «передача новим людям старого знання (i здібностей) для того, щоб також і ці люди спромоглись постаріти. Це не виключає креативності та інновацій, але значною мірою релятивізує їхнє значення, оскільки порівняно із традицією інновація має обмежене значення» [17: 76]. Обмежене значення інновацій у культурі обумовлено як їхніми власними життєвими циклами, так й особливостями людської психології, яка має межі сприйняття інновацій. Але передусім своєрідний інноваційний фільтр встановлюють самі соціальні системи. Суспільна свідомість, так само, як і індивідуальна, тут вдається до хитрощів: маскує старе під нове, підтримує баланс між старим і новим через введення до культури ретроінновацій тощо. Наведемо опис цього процесу, запропонований А. Тремлєм: «Забагато нового може бути нестерпним i, попри темпоралізації селекційного відбору, воно вже не здатне виконувати компенсаторну функцію, яка стає соціально витратною. Але ми помічаємо це запізно. Отже, заміна старого на нове (у вигляді нової жінки, нового чоловіка, нової професії, а також ланцюга реформ тощо) є тільки заміною знайомих проблем на незнайомі. У нормальному випадку ми живемо не у новому, а у старому, а саме: у наших звичках. Нове у численних його проявах має потребу у старому не тільки для того, щоб його відкинути, а й для того, щоб зробити себе більш прийнятним як нове. Через музеїзацію старого... ми компенсуємо надмір нового, щоб бути у змо- 
зі його зносити» [17: 75]. Контрфактичність нової людини та емпірична даність старої, тобто представника тієї генерації, яка виховує нову людину, ускладнюють не тільки розуміння біографічної транстемпоральності, а й взагалі взаємозв'язку людського буття і часу. Особливо це торкається прийдешності, яка у парадоксальний спосіб мислиться як щось принципове нове, але у знайомих і зрозумілих контекстах.

Не менш складною методологічною проблемою, ніж взаємозв'язок Нового і Старого в культурі та освіті, $\epsilon$ співвідношення між знанням і незнанням. Формальне розв'язання цієї проблеми, яка також має культурноантропологічний аспект, втрачає будь-який сенс, бо прискорене старіння знань, удосконалення механізмів його селекції та трансляції ставлять під сумнів будь-яку дефініцію знання. Можна погодитись з німецьким дослідником перспектив суспільства знань К. Губіхом, який звертає увагу на такий момент: « Якщо ми при визначенні знання будемо виходити 3 того, що таке «знання», то оберемо хибну стартову позицію. Адже через це ми неминуче зав'язнемо в ітеративному процесі продукування знання про знання через знання тощо. До того ж, на кожному ступені треба було б вступати у полеміку з різними - філософськими, лінгвістичними, кібернетичними, соціологічними, економічними, інженерно-технологічними - пропозиціями щодо визначення змісту цього поняття» [8: 15] Значно менш зауваг, на його думку, викликає типологічний розподіл знань на «знання про те, що $\epsilon$, знання про те, що може бути, знання про те, що повинно бути» [8: 19]. Кожне суспільство внаслідок історичних обставин, особливостей національної культури, рівня соціально-економічного розвитку, політичного устрою, впливу глобалізаційних тенденцій тощо, формує також різні моделі співвідношення між цими типами знань. Так, клерикальні і тоталітарні суспільства віддають перевагу деонтичному знанню орієнтованому на належне. Через сакралізацію належного практики інквізиції легко адаптуються до умов тоталітарної культури модерних суспільств, підкоряючи знання про те, що $\epsilon$, раз і назавжди визначеному належному. Про це переконливо свідчить історія науки та освіти у Третьому рейху, де домінувала ідея належного з вимогою підкорення об’єктивної істини волюнтаристським імперативам, наприклад через «німецьку волю до пізнання» або через стратегію «тотальної науки» [10: 81, 187]. У демократичних суспільствах, навпаки, саме через акцентування значущості знання про те, що може бути, а може й не бути, тобто про контингетність тенденцій розвитку суспільства і культури, пропорції між означеними типами знань вирівнюється, що знаходить прояв у навчальних планах і програмах, проектах наукових досліджень тощо. Прозорість наукового виробництва за умов демократії, його доступність і популяризація, хоча і $є$ позитивними тенденціями, але вони також мають свої ризики.

Про перетворення знання предмет широкого вжитку у масовій культурі вже йшлось вище. Суспільства споживання, виникаючи на грунті держав добробуту та благополуччя (Wohlstand- und Wohlfahrtstaaten) криють у собі небезпеку утилітаристського використання знання, віддаючи перевагу знанню про те, що є, перед знанням про належне і можливе. До того ж тут через радикалізацію опозиції «відкритість-закритість» і використання можливостей інформаційних технологій надзвичайно загострюється проблема припустимої міри прагматизації знання. Встановлення такої міри необхідно не тільки для визначення освітніх стандартів, а й підтримування життєздатності суспільства знань як соціальної системи. Тимчасові припинення певних дискурсів, наприклад, необхідно для того, щоб ефективно діяли морально-правові регулятиви. «Моральні норми, слушно підкреслює К. П. Лісман, - функціонують тільки тоді, коли ми відмовляємось інструменталізувати знання, як виникли ці норми, що вони означають і кому вони корисні» [11: 26]. Деякі дослідники, оптимістично оцінюючи перспективу самоствердження суспільства знань як ери інновацій і радикального оновлення людства, вбачають запорукою гуманістичного спрямування його розвитку владне самоствердження так званої «епістемократії» [див. 2]. Дійсно, між владою і знанням, як вже зазначалося вище, завжди існував і існує взаємозв'язок. У суспільстві знань він значно посилюється, але це не означає автоматичного посилення ролі інтелігенції, рівня їі моральної свідомості тощо, а також створення умов для реалізації численних проектів безперервної освіти. Аналізуючи ту ситуацію, яка склалася у Західній Європі, Р. Маркс констатує: «Дитина 3 родини із високим соціальним статусом має у сім разів більше шансів отримати вищу освіту, ніж та, що походить 3 родини з низьким соціальним статусом. ... Соціальна непрозорість системи освіти суспільства, яке ми все більш розуміємо як суспільство знань, накладає свій відбиток на професійне майбутнє індивіда, яке залежить від дипломів та освітніх сертифікатів, потрібних при працевлаштуванні» [14: 105-106]

Яким буде сукупний профіль знання у суспільстві, підвалинами якого стають знання, — це залежить від здатності людства управляти процесами свого розвитку, здійснювати контроль і самоконтроль. Найбільш загальне розуміння знання як визнаного і верифікованого результату пізнання вказує на його внутрішній зв'язок з домінуючими уявленнями про критерії знання і незнання істини і заблудження. Отже, знання завжди пов'язано 3 уявленнями про нього, з картиною світу, в рамках якої утворюється специфічна епістемна культура. Через це все більше стверджується думка про «плюралізм культур знання», розглядаючи їх як відповідні «практики, механізми та принципи соціально організованої пізнавальної діяльності», знання ж визначається як «культура у горизонті соціального» [15: 74]. 
В рамках цієї культури знання далеко не в останню чергу визначається через його відрізнення від незнання. Незнання у цьому сенсі виконує спонукально-орієнтуючу функцію. Адже усвідомлення незнання поглиблює уявлення про природу та антропологічне підгрунтя знання. Те, що продукування знання $\epsilon$ також продукуванням незнання у його позитивному сенсі, людство усвідомлювало ще в античності. Незнання, як свідчать сучасні міждисциплінарні дослідження у галузі людинознавства, є складовою антропосоціогенезу. Воно - як встановлення обмеженості культурного виміру існуючого знання - конституює у негативний, але досить ефективний спосіб простір для людської діяльності. Незнання, яке не треба плутати з невіглаством, тобто суб'єктивно обмеженим знанням, або неосвіченістю та необізнаністю, має антропологічне значення. Як контрфактичність існуючій реальності, воно виконує розвантажну функцію, пригальмовує оберти спекулятивного мислення, відкриваючи простір для дій, що втілюють ідеї. А. Тремль вказує на антропологічні ризики відриву теорії від практики: «Тому, хто забагато знає, загрожує небезпека забагато думати, через що він зрештою стає нездатним діяти. Теоретична рефлексія, якщо вона постійно передує дії, викликає щось на зразок ступору перед прийняттям рішення» [16: 152].

У модерній культурі протягом кількох століть формувалося зневажливе ставлення до незнання. Ейфорія від прискорення процесу пізнання і наукового виробництва, притаманне ранньому Модерну, породжує ілюзію щодо можливості остаточної перемоги над незнанням. Упередження щодо сократівської гносеологічно-педагогічної позиції закріплюються ідеологією Просвітництва. Енциклопедія стає одним із символів цієї доби, а енциклопедист - взірцем освіченої людини. Розкриваючи цей бік діалектики Просвітництва, А. Тремль зауважує: «Негативне ставлення до незнання, яке згодом починає ототожнюватися 3 нерозумністю та ледарством, є зворотним боком завищеної оцінки знання, яке емфатично підганяється під мудрість і стає довготривалим завданням педагогіки. ... Знання стає функціональним еквівалентом сили. Доки існувала єдність теоретичного і практичного розуму, таке надання переваги знанню було суто етичним» [16: 154 ]. Значний приріст індивідуального, фрагментарного і розгалуженого незнання, який супроводжує процес конституювання суспільства знань в свою чергу стає дестабілізуючим чинником суспільного буття через незупинний процес прискореної появи нових невизначеностей. Нове незнання принципово відрізняється від старого. Якщо раніше знання і незнання були закріплені нормативно, а старіння знання не викликало розгубленості і навіть відчаю, то за сучасних умов змінюється соціально-антропологічний статус незнання. Останнє вже не є прогалиною у знаннях, яку треба заповнити. Воно явно і неявно супроводжує життєтворчість людини, поводження з ним стає складовою мистецтва жити.

Суспільство знань, що змушено стверджуватись у мінливих контекстах нового незнання, посилює значущість соціального і організаційного навчання. Передусім це торкається його організації, бо процеси навчання і виховання тут не можуть протікати у тих формах, які були притаманні індустріальному суспільству. Постіндустріальні тенденції розвитку сучасних соціумів вказують на те, що у перспективі зникають лінії демаркації між соціальними просторами, виокремлення яких свого часу було цивілізаційним поступом. Сучасні комунікаційні технології дозволяють якщо не усунути, то принаймні зробити максимально прозорою межу між домом і працею, домом і навчанням. Суспільство знань, більш, ніж будь-яке дотепер, стає суспільством індивідів. Це означає, що старі ієрархічно побудовані форми координації вже не є дієвими за умов різких змін соціокультурних та епістемних ситуацій [див. 7: 109]. Мабуть вперше в історії економічні організації такого суспільства, мається на увазі як економіка взагалі, так і економіка наукового виробництва та економіка освіти, починають займатися самоаналізом і цілеспрямовано, а не спонтанно вчитися на власному досвіді. Суспільство знань значно розширює межі свого соціального та організаційного навчання, спираючись на свої власні культуральні структури. Їх завданням $є$ мінімізація соціальних і культурних ризиків, запобігання психічних травм усіх без винятку генерацій населення, які набувають досвіду прискоренного суспільного оновлення. Усе це потрібне, щоб розвиток суспільства знань йшов не у напрямку відчуження людини, а зі збереженням потенційно закладеної у ньому гуманістичної спрямованості.

У підсумку треба зазначити, що розгляд суспільства знань у проблемному полі культуральної соціології дозволяє створити динамічну модель останнього із залученням широкого теоретичного досвіду концептуалізації сучасних транзитивних суспільств та постійно змінюваних соціокультурних контекстів.

\section{Література}

1. Колпаков А. Общество знания. Опыт философско-методологического анализа // Вопросы философии, 2000. № 4. С. $26-38$.

2. Копилов В. О. Влада і знання генезис ідеї епістемократії. Х.: НАУ ім. М.С. Жуковського «ХАІ», 2009. 514 с.

3. Інформаційне суспільство і культура / В. В. Лях, В. С. Пазенок, Я. В. Любивий та ін. // Інформаційне суспільство у соціально-філософській ретроспективі та перспективі. К.: ТОВ «ХХІ століття діалог культур», 2009. С. 10-44.

4. Eagleeton Terry. Culture and Barbarism. Metaphysic in a Time of Terror// Commonweal. A review of religion, politics, and culture. March 27, 2009, Vol. CXXXVI, N 6. P. 11. 
5. Glißmann Wilfried Die neue Selbstständigkeit in der Arbeit // Unterwegs zur Wissensgesellschaft: Grundlagen — Trends — Probleme/ Hrsg.: Christoph Huber. Berlin: Ed. Sigma, 2000. S.135-150.

6. Habermas Jürgen. Glauben und Wissen. Friedenpreis des Deutschen Buchhandels 2001. Frankfurt am Main: Suhrkamp. 2002. $48 \mathrm{~S}$.

7. Heidenreich Martin. Die Organisation der Wissensgesellschaft.// Unterwegs zur Wissensgesellschaft: Grundlagen — Trends — Probleme/ Hrsg.: Christoph Huber. Berlin: Ed. Sigma, 2000. S. 107-119.

8. Hubig Christoph. Einführung Was leistet eine Grundlagen Diskussion? Unterwegs zur Wissensgesellschaft: Grundlagen Trends - Probleme/ Hrsg.: Christoph Huber. Berlin: Ed. Sigma. 2000. S. 15-24.

9. Joas Hans. Braucht der Mensch Religion. Über Erfahrungen der Selbsttranszendenz. Freiburg am Breisgau: Fink, 2004. 234 S.

10. Leske Monika. Philosophen im Dritten Reich. Studie zu Hochschul- und Philosophiebetrieb im faschistischen Deutschland. Berlin: Dietz Verlag, 1990. 318 S.

11. Liessmann Konrad Paul. Philosophie des verbotenen Wissens. Wien: Paul Zsolnay Verlag, 2001, 243 S.

12. Liessmann Konrad Paul. Theorie der Unbildung. Die Irrtümer der Wissensgesellschaft. Wien: Paul Zsolnay Verlag, 2006.275 S.

13. Lyotard J.F. Das Postmoderne Wissen. Wien: Paul Zsolnay Verlag, 1986. 198 S.

14. Marx Reinhard. Das Kapital. Ein Plädoyer für den Menschen. München: Pattloch Verlag, 2008. 320 S.

15. Sandkühler Hans Jörg. Kritik der Repräsentation. Einführung in die Theorie der Überzeugungen, der Wissenskulturen und des Wissens. Frankfurt am Main, 2009-280 S.

16. Treml Alfred K. Allgemeine Pädagogik. Grundlagen, Handlungsfelder und Perspektiven der Erziehung- Stuttgart-BerlinKöln: Kohlhammer, 2000. 304 S.

17. Treml Alfred K. Das alte und das Neue . Erziehung zur Kreativität aus evolutionstheoretischer Sicht // Alfred K. Treml (Hrsg.) Das Alte und das Neue. Erziehung zur Kreativität aus evolutionstheoretischer Sicht Münster, 2004, S. 67-79.

18. Welsch Wolfgang. Unsere postmoderne Moderne. Berlin: Akad. Verlag, 1993. 344 S.

19. Willke H. Atopia. Studien zu atopischen Gesellschaft. Frankfurt am Main: Suhrkamp, 2001. 263 S. 